\title{
Contribution to the knowledge of polypores (Agaricomycetes) from the Atlantic forest and Caatinga, with new records from Brazil
}

\author{
Baltazar JM ${ }^{1,2} *$, Drechsler-Santos $\mathrm{ER}^{1,3}$, Ryvarden $\mathrm{L}^{4}$, Cavalcanti MAQ ${ }^{1}$ and Gibertoni TB $^{1}$ \\ ${ }^{1}$ Departamento de Micologia, Universidade Federal de Pernambuco. Av. Nelson Chaves s/n, CEP 50670-420, Recife, \\ PE, Brazil \\ ${ }^{2}$ current address: Programa de Pós-Graduação em Botânica, Departamento de Botânica, Universidade Federal do Rio \\ Grande do Sul, Av. Bento Gonçalves 9500, CEP 91501-970, Porto Alegre, RS, Brazil \\ ${ }^{3}$ current address: Departamento de Botânica, PPGBVE, Universidade Federal de Santa Catarina. Campus Trindade, \\ CEP 88040-900, Florianópolis, SC, Brazil \\ ${ }^{4}$ Departament of Botany, University of Oslo, Blindern. P.O. Box 1045, N-0316 Oslo, Norway
}

Baltazar JM, Drechsler-Santos ER, Ryvarden L, Cavalcanti MAQ, Gibertoni TB 2012 Contribution to the knowledge of polypores (Agaricomycetes) from the Atlantic forest and Caatinga, with new records from Brazil. Mycosphere 3(3), 267-280, Doi 10.5943 /mycosphere/3/3/1

The Atlantic Forest is the better known Brazilian biome regarding polypore diversity. Nonetheless, species are still being added to its mycota and it is possible that the knowledge of its whole diversity is far from being achieved. On the other hand Caatinga is one of the lesser known. However, studies in this biome have been undertaken and the knowledge about it increasing. Based in recent surveys in Atlantic Forest and Caatinga remnants in the Brazilian States of Bahia, Pernambuco and Sergipe, and revision of herbaria, twenty polypore species previously unknown for these states were found. Fuscoporia chrysea and Inonotus pseudoglomeratus are new records to Brazil and nine are new to the Northeast Region. Furthermore, four species previously known from Brazil were found for the first time in the Atlantic Forest, viz. Flabellophora parva, F. chrysea, I. pseudoglomeratus and Trametes lactinea, and three in the Caatinga, viz. I. portoricensis, Phylloporia spathulata and Schizopora flavipora. Keys to the main taxa are provided.

Key words - Basidiomycota - Hymenochaetales - Neotropical mycota - Polyporales - taxonomy

Article Information

Received 2 April 2012

Accepted 11 April 2012

Published online 11 May 2012

*Corresponding author: Juliano M. Baltazar - e-mail - baltazarjmb@ gmail.com

\section{Introduction}

Studies of polypores in Brazil have mainly focused on the Atlantic Forest biome. Baltazar \& Gibertoni (2009) and Baltazar et al. (2009a) compiled the literature records for this group of fungi in this biome, and listed 339 species names. However, even with the main mycological effort focused in the Atlantic Forest biome, it seems that we are still far from knowing the whole polypore diversity. A further 24 species have been added to the Atlantic Forest list by Drechsler-Santos et al.
(2008), Silveira et al. (2008 [“2009”]), Baltazar et al. (2009b, 2010a,b, unpublished data), Campacci \& Gugliotta (2009), Coelho et al. (2009), Gomes-Silva et al. (2010a), Gugliotta et al. (2010), Meijer (2010), Westphalen et al. (2010a,b), Gibertoni et al. (2011) and Reck et al. (2011). Seven of these species were described as new taxa, while 11 were reported for the first time in Brazil. These studies and many others also report new distributional data on some previously known species within the Atlantic Forest. 
On the other hand, the Caatinga biome (Brazilian semi-arid) has been neglected for a long time and the re-evaluation of lignocellulolytic Agaricomycetes diversity made by Drechsler-Santos et al. (2009) listed only 37 species, 29 of them being polypores. After that revision, Drechsler-Santos et al. (2010) and Gibertoni et al. (2011) added 10 species (seven Phellinus Quél. s.l. and three Trichaptum Murrill), increasing the number of polypore species known from the Caatinga to 39.

The aim of the present work is to report new distributional data on species found during a recent survey carried out by us, and to present taxonomical comments on those species. Keys to the main taxa are also provided.

\section{Methods}

Four Atlantic Forest remnants in the Brazilian State of Pernambuco were surveyed for their polypore diversity. Two are lowland Atlantic Forest areas: Parque Dois Irmãos ( $\left.8^{\circ} 15^{\prime} \mathrm{S}, 35^{\circ} 57^{\prime} \mathrm{W}\right)$ and Reserva Particular do Patrimônio Natural Carnijó (RPPN Carnijó) $\left(8^{\circ} 10^{\prime} \mathrm{S}, 35^{\circ} 05^{\prime} \mathrm{S}\right)$, and two are enclaves of Atlantic Forest in the Semi-arid region, also known as 'brejos de altitude': Parque Ecológico João de Vasconcelos Sobrinho ('brejo dos cavalos') ( $\left.8^{\circ} 16^{\prime} \mathrm{S}, 35^{\circ} 58^{\prime} \mathrm{W}\right)$ and Mata do Estado $\left(7^{\circ} 35^{\prime} \mathrm{S}, 35^{\circ} 30^{\prime} \mathrm{W}\right)$.

The three Caatinga remnants surveyed are: Parque Nacional do Catimbau (08 $24^{\prime}$ ' $08^{\circ} 36^{\prime} \mathrm{S}$ and $37^{\circ} 09^{\prime}-30^{\circ} 14^{\prime} \mathrm{W}$ ), which area covers the Buíque, Ibimirim and Tupanatinga minicipalities, and Sítio Carro Quebrado $\left(07^{\circ} 50^{\prime} \mathrm{S}, 38^{\circ} 06^{\prime} \mathrm{W}\right)$, both areas in the State of Pernambuco, and Porto da Folha municipality ( $9^{\circ} 54^{\prime}$ S, $37^{\circ} 16^{\prime} \mathrm{W}$ ) in the State of Sergipe.

Specimens kept in HUEFS originating from the State of Bahia were analysed; they are from Serra da Jibóia ( $\left.12^{\circ} 51^{\prime} \mathrm{S}, 39^{\circ} 28^{\prime} \mathrm{W}\right)$, Serra do Orobó $\left(12^{\circ} 28^{\prime} \mathrm{S}, 40^{\circ} 31^{\prime} \mathrm{W}\right)$ and Serra Maravilha $\left(10^{\circ} 24^{\prime} \mathrm{S}, 40^{\circ} 12^{\prime} \mathrm{W}\right)$, all Atlantic Forest enclaves within the Caatinga biome.

For species distribution in the Brazilian states, the following abbreviations are used: Acre-AC, Alagoas-AL, Amazonas-AM, BahiaBA, Minas Gerais-MG, Pará-PA, Paraíba-PB, Paraná-PR, Pernambuco-PE, Rio Grande do Norte-RN, Rio Grande do Sul-RS, RondôniaRO, Roraima-RR, Santa Catarina-SC and São
Paulo-SP. Biomes are given after states abbreviations between brackets as follow: Amazonian Forest-(am), Atlantic Forest-(af), Cerrado-(ce), Caatinga-(ca), exotic vegetation(ex), and not indicated in the original citation(ni). We adopted the classification of Brazilian biomes given in IBGE (2011).

Basidiomata were cut by hand for microscopic study, and sections were mounted in 3\% $\mathrm{KOH}$ and Melzer's reagent (IKI). All specimens were deposited in URM, some with duplicates in O. Herbaria acronyms follow Thiers (2012).

\section{Taxonomy}

Fomitopsidaceae Jülich

Laetiporus sulphureus (Bull.:Fr.) Murrill, Mycologia 12(1): 11, 1920.

$\equiv$ Boletus sulphureus Bull., Herb. Fr. 9: tab. 429, 1789.

Description - Ryvarden \& Johansen (1980) and Burdsall \& Banik (2001).

Known distribution - Cosmopolitan (Ryvarden \& Johansen 1980); in Brazil: BA(ca, ni), PR(af), RS(af), SC(af), SP(af), (Góes-Neto 1999, Baltazar \& Gibertoni 2009), and $\mathrm{PE}(\mathrm{af})$. This is its first report from the State of Pernambuco and the Caatinga.

Material examined - Bahia, Santa Teresinha, Distrito de Pedra Branca, Serra da Jibóia, 14 May 2007, A. Góes-Neto 32 (HUEFS 132226, O). Brazil, Bahia, Rui Barbosa, Serra do Orobó, Fazenda Riacho do Meio, 20 Aug 2005, D. Cardoso 1173 (HUEFS 106069, O). Brazil, Pernambuco, Moreno, RPPN Carnijo, at the base of a living hardwood, 12 Mar 2009, J.M. Baltazar \& L. Trierveiler-Pereira, JMB 1444 (URM 81365).

Notes - This species is easily recognized in the field by its fleshy, soft, citric yellow to orange basidiomata, which become light and brownish when dry. Microscopically the species is characterized by its monomitic hyphal system with simple-septate hyphae, and hyaline, ovoid to ellipsoid basidiospores.

We have used a wide concept for this species. Recent studies have demonstrated that the previous concept has to be split into several species, especially in North America (Lindner $\&$ Banik 2009). The earliest name for collections named $P$. sulphureus made in the 


\section{Key to Laetiporus Murrill species known for the Neotropics}

1. Basidiomata excentrically to centrally stipitate, brown and sometimes with shades of pink

L. persicinus

1. Basidiomata laterally stipitate to pileate sessile, citric yellow to orange $\quad$ L. sulphureus s.1.............

tropical zone is Laetiporus discolor (Klotzsch) Corner (三 Polyporus discolor Klotzsch 1833) based on a collection from Mauritius in the Indian Ocean. The next name in priority order is Laetiporus miniatus (Jungh.) Overeem ( Polyporus miniatus Jungh. 1828) based on a collection from Java. Thus, further investigations with molecular evidence may well show that the tropical taxa within this complex are different from L. sulphureus, which was based on European collections.

Laetiporus persicinus (Berk. \& M.A. Curtis) Gilb., another species of the genus also reported from Brazil, differs by its stipitate and pinkish brown basidiomata (Burdsall \& Banik 2001).

\section{Ganodermataceae Donk}

Ganoderma chalceum (Cooke) Steyaert, Bull. Jard. Bot. Nat. Belg. 37: 481, 1967.

$\equiv$ Polyporus chalceus Cooke, Trans. \& Proc. Bot. Soc. Edinb. 13: 135, 1879.

Description - Ryvarden (2004) and Westphalen et al. (2010a).

Known distribution - Pantropical, but in the Neotropics known only from Colombia and Brazil, where it is known from RS(af) (Westphalen et al. 2010a) and PE(af, ca). This is its first report from the Northeast Region and the Caatinga.

Material examined - Pernambuco, Recife, Parque Dois Irmãos, on a fallen trunk of unknown hardwood, 10 Mar 2009, J.M. Baltazar et al., JMB 1383 (URM 81393). Pernambuco, Triunfo, Sítio Carro Quebrado, on unidentified living host, 7 Oct 2008, Silva 001 (URM 80457, O).

Notes - The basidiospores of this species are similar in size to those of $G$. resinaceum Boud., and these species are almost identical microscopically (Ryvarden 2004). However, the former has a black resinous band in the context, which the later lacks (Westphalen et al. 2010a).

Macroscopically, one could take $G$. chalceum as a sessile basidioma of $G$. stipitatum (Murrill) Murrill, but they can be separated by basidiospore size $(9-12 \mu \mathrm{m}$ in the largest dimension in the former, and 7-9.5 $\mu \mathrm{m}$ in the later).

A key to Ganoderma P. Karst. species known from the Neotropics is given in Ryvarden (2004).

Grammotheleaceae Berk. \& M.A. Curtis Grammothele cf. fuligo (Berk. \& Broome) Ryvarden, Trans. Br. mycol. Soc. 73(1): 15, 1979.

$\equiv$ Polyporus fuligo Berk. \& Broome, J. Linn. Soc., Bot. 14(2): 53, 1875.

Description - Ryvarden \& Johansen (1980) and Reck \& Silveira (2009).

Known distribution - Pantropical (Ryvarden \& Johansen 1980); in Brazil: $\mathrm{AM}(\mathrm{am}), \mathrm{PA}(\mathrm{am}), \mathrm{RR}(\mathrm{am}), \mathrm{RS}(\mathrm{af}), \mathrm{SC}(\mathrm{af})$ (Baltazar \& Gibertoni 2009, Gomes-Silva \& Gibertoni 2009, Reck \& Silveira 2009), PE(af). This is its first report from the Northeast Region and the Caatinga.

Material examined - Pernambuco, Moreno, RPPN Carnijó, on a dead leaf of a palm, 14 Aug 2008, J.M. Baltazar et al., JMB 695 (URM 81754).

Notes - This species is characterized by its bluish to greyish basidiomata, tiny pores, and occurrence on monocotyledons (Reck \& Silveira 2009). These features also distinguish it from the two other Grammothele Jülich species found in Brazil.

Despite the fact that this specimen was sterile, all other features fit with those of $G$. fuligo, including the substrate.

A key to Grammothele species known from Brazil is given in Reck \& Silveira (2009).

Hymenochaetaceae Imazeki \& Toki

A key to Phellinus s.l. species known from the Neotropics is given in Ryvarden (2004).

Fulvifomes merrillii (Murrill) Baltazar \& Gibertoni, Mycotaxon 111: 206, 2010. $\equiv$ Pyropolyporus merrillii Murrill, Bull. 
Torrey Bot. Club 34: 479, 1907.

Description - Ryvarden (2004).

Known distribution - Probably pantropical but rare in many areas (Baltazar \& Gibertoni 2010); in Brazil: BA(af, ca), PR(af) (Baltazar \& Gibertoni 2009) and PE(af). This is its first report from the State of Pernambuco.

Material examined - Pernambuco, Recife, Parque Dois Irmãos, on a fallen trunk of unknown hardwood, 16 Sep 2008, J.M. Baltazar et al., JMB 860 (URM 81295). Ibid, 7 May 2009, J.M. Baltazar \& L. TrierveilerPereira, JMB 1568 (URM 81296).

Notes - Fulvifomes merrillii is close to $F$. rimosus (Berk.) Fiasson \& Niemelä, differing by its smaller pores $(4-5$ per $\mathrm{mm}$ in the former, $7-10$ per $\mathrm{mm}$ in the later). Phellinus piptadeniae Teixeira, another close species, also has larger pores (4-5 per $\mathrm{mm}$ ) and smaller basidiospores $(4-5 \times 3.5--4 \mu \mathrm{m}$ in $P$. piptadeniae, 5-6 x 4-5 $\mu \mathrm{m}$ in $F$. merrillii). Other data such as compatibility tests and molecular studies are needed to better understand the relationships within the $F$. rimosus complex.

Fuscoporia chrysea (Lév.) Baltazar \& Gibertoni, Mycotaxon 111: 206, 2010.

$\equiv$ Polyporus chryseus Lév., Ann. Sci. Nat., Bot., sér. 3, 5: 301, 1846.

Description - Ryvarden (2004).

Known distribution - Neotropical (Ryvarden 2004, Baltazar \& Gibertoni 2010). This is its first report from the Atlantic Forest and Brazil as well.

Material examined - Pernambuco, São Vicente Férrer, Mata do Estado (Sirijí), on a fallen trunk of unknown hardwood, 21 Oct 2008, J.M. Baltazar et al., JMB 1164 (URM 81293).

Notes - This species is characterized by the effuse-reflexed basidiomata with small, imbricate pilei. Fuscoporia gilva (Schwein.) T. Wagner \& M. Fisch. is similar but differs by its larger basidiomata, the colour of the hymenophore and the pore size (brown, 6-8 pores per $\mathrm{mm}$ in this species, and yellowish, 56 per $\mathrm{mm}$ in $F$. chrysea).

Since there are few collections of $F$. chrysea, Ryvarden (2004) asserted that the current species concept could comprises only an initial development phase of the basidiome, and a larger pileus could develop later.

Fuscoporia ferrea (Pers.) G. Cunn., Bull. New Zealand Dept. Sci. Industr. Res. 73: 7, 1948.

$\equiv$ Polyporus ferreus Pers., Mycol. Eur. 2: 89,1825 .

Description - Cunningham (1965) and Ryvarden (2004).

Known distribution - Cosmopolitan (Ryvarden 2004); in Brazil: RS(af), SC(af), SP(af) (Baltazar \& Gibertoni 2009) and PE(af). This is its first report from the Northeast Region.

Material examined - Pernambuco, Recife, Parque Dois Irmãos, on a fallen trunk of unknown hardwood, 13 Jun 2008, J.M. Baltazar et al., JMB 356 (URM 81180).

Notes - This species differs from $F$. ferruginosa (Schrad.) Murrill by the presence of setal hyphae in the latter. Fuscoporia punctatiformis (Murrill) Zmitr. et al., another similar species, has smaller basidiospores (5$7.5 \times 2-2.5 \mu \mathrm{m}$ in $F$. ferrea and 4-6 x 1.5-2 $\mu \mathrm{m}$ in $F$. punctatiformis) (Ryvarden 2004).

Inonotus portoricensis (Overh.) Baltazar \& Gibertoni, Mycotaxon 111: 2062010.

$\equiv$ Fomes portoricensis Overh., in Seaver \& Chardón, Sci. Surv. Porto Rico \& Virgin Islands 8(1): 158, 1926.

Description - Fidalgo (1968b) and Ryvarden (2004).

Known distribution - Neotropical (Baltazar \& Gibertoni 2010), Java? (cf. Lowe 1957 and Fidalgo 1968b); in Brazil: AL(af) and $\mathrm{BA}(\mathrm{af}, \mathrm{ca})$. This is its first record from the State of Pernambuco and the Caatinga.

Material examined - Bahia, Santa Teresinha, Serra da Jibóia, 16 Feb 2002, J.L.A. Dias 17 (HUEFS 61548). Pernambuco, Recife, Parque Dois Irmãos, on a fallen trunk of unknown hardwood, 7 Jul 2008, J.M. Baltazar et al., JMB 500, 504 (URM 81297, 81298). Ibdi, 16 Sep 2008, J.M. Baltazar et al., JMB 836 (URM 81299). Ibid, 19 Nov 2008, J.M. Baltazar \& L. Trierveiler-Pereira, JMB 1223, 1224 (URM 81300, 81301). Ibid, 10 Mar 2009, J.M. Baltazar et al., JMB 1401 (URM 81302). Ibid, 7 May 2009, J.M. Baltazar \& L. Trierveiler-Pereira, JMB 1547 (URM 81303).

Notes - This species belongs to the $I$. pachyphloeus (Pat.) T. Wagner \& M. Fisch. 
Key to Inonotus s.l. species known from Brazil-updated from Baltazar et al. (2010b)

1. Basidiospores olivaceous brown in $\mathrm{KOH}$ Aurificaria luteoumbrina (Romell) D.A. Reid

1. Basidiospores hyaline or different colour 2

2. Setal hyphae present 3

2. Setal hyphae absent 8

3. Chlamydospores usually present in the context Inonotus rickii (Pat.) D.A. Reid

3. Chlamydospores absent in the context 4

4. Basidiospores globose to subglobose, $10-13 \mu \mathrm{m}$ in the largest dimension Inonotus micantissimus (Rick) Rajchenb.

4. Basidiospores ovoid to ellipsoid, 5-8 $\mu \mathrm{m}$ in the largest dimension 5

5. Context pseudo homogeneous, upper tomentum soon disappearing and exposing a black line, hyphal system pseudo dimitic to monomitic, basidiospores first yellowish becoming pale rusty brown with age Inonotus portoricensis

5. Context homogeneous, hyphal system monomitic, basidiospores hyaline to pale yellow 6

6. Pileus with a distinct umbo, pileal surface glabrous and concentrically sulcate, 4-6(-8) pores per $\mathrm{mm}$ Inonotus pseudoglomeratus

6. Pileus without umbo, pileal surface finely tomentose or velutineous to glabrous with age, but then even, 3-4 pores per mm

7. Hymenial setae rare, $15-21 \times 5-9 \mu \mathrm{m}$, basidiospores (5.5)6.0-8.0 $\mu \mathrm{m}$ in the largest dimension .... Inonotus patouillardii (Rick) Imazeki

7. Hymenial setae frequent, $15-40 \times 6-14 \mu \mathrm{m}$, basidiospores $5.0-6.0(-6.5) \mu \mathrm{m}$ in the largest dimension Inonotus radiatus (Sowerby) P. Karst.

8. Hymenial setae present

8. Hymenial setae absent

9. Hymenial setae hooked

Inonotus fulvomelleus Murrill

9. Hymenial setae straight

10. Basidiomata resupinate, 7-9 pores per $\mathrm{mm}$, basidiospores pale yellow to pale brown Inonotus tropicalis (M.J. Larsen \& Lombard) T. Wagner \& M. Fischer.

10. Basidiomata pileate, $3-6$ pores per $\mathrm{mm}$, basidiospores hyaline

11.Basidiomata pileate sessile, flabelliform to fan-shaped, pileus dimidiate, hymenial setae ventricose $20-50$ x $8-14 \mu \mathrm{m}$ Inonotus pseudoradiatus (Pat.) Ryvarden

11.Basidiomata effused-reflexed, pileus semi-circular, applanate, hymenial setae subulate 30-40 x 4-7 $\mu \mathrm{m}$ Inonotus xanthoporus Ryvarden

12. Basidiomata always resupinate Inonotus venezuelicus Ryvarden

12. Basidiomata effused-reflexed to pileate sessile 13

13. Basidiospores hyaline to pale yellow Inonotus splitgerberi (Mont.) Ryvarden

13. Basidiospores rusty to reddish brown 14

14.Basidiomata effused-reflexed to pileate sessile, pileus dimidiate to triquetrous, pileal surface 
warted, blackish and wrinkled Inocutis jamaicensis (Murrill) A.M. Gottlieb et al. 14.Basidiomata pileate sessile to substipitate, pileus flabelliform, pileus surface even, yellowish to brown and not wrinkled Inocutis porrecta (Murrill) Baltazar

complex, differing by the pseudo homogeneous context in I. portoricensis, which means that its tomentum disappears soon and a black line is exposed (Fidalgo 1968b). Following this author, this is a unique species in the complex, which has pigmented basidiospores from the beginning of basidioma development.

The hyphal system of $I$. portoricensis is intermediated between mono- and dimitic, with generative hyphae of two types: 1) hyaline and thin-walled; 2) yellowish and slightly thickwalled, with distant septa. Setal hyphae and hymenial setae are also present.

Inonotus pseudoglomeratus Ryvarden, Syn. Fungorum 15: 78, 2002.

Description - Ryvarden (2004, 2005).

Known distribution - Neotropical but rare (Ryvarden 2004, 2005). This is its first report from the Atlantic Forest and Brazil as well.

Material examined - Pernambuco, Recife, Parque Dois Irmãos, on a fallen trunk of unknown hardwood, 15 Oct 2008, J.M. Baltazar \& L. Trierveiler-Pereira, JMB 1082 (URM 81290, O). Ibid, 10 Mar 2009, J.M. Baltazar et al., JMB 1430 (URM 81291).

Notes - This species is characterized by the concentrically zoned and umbonated pileus, the olivaceous yellow hymenophore and rare hymenial setae. Inonotus glomeratus (Peck) Murrill from the temperate North America is similar, but it has resupinate basidiomata and abundant hymenial setae.

Inonotus patouillardii (Rick) Imazeki is also similar, but has a non zonated, cracking pileal surface, larger pores and basidiospores (3-4 pores per $\mathrm{mm}, 6-8 \times 4-5.5 \mu \mathrm{m}$ in $I$. patouillardii; 4-6 pores per mm, 5-6 x 4-4.5 $\mu \mathrm{m}$ in I. Pseudoglomeratus) (Ryvarden 2004).

Phylloporia spathulata (Hook.) Ryvarden, Syn. Fungorum 5: 196, 1991.

$\equiv$ Boletus spathulatus Hook., Syn. Pl. (Kunth) 1: 9, 1822.

Description - Wagner \& Ryvarden

(2002) and Ryvarden (2004).

Known distribution - Pantropical
(Wagner \& Ryvarden 2002); in Brazil: AM(am), BA(af, ca), MG(af), PB(af), PR(af), RO(am), RS(af), SC(af), SP(af, ce) (Baltazar \& Gibertoni 2009, Gomes-Silva \& Gibertoni 2009, Gibertoni \& Drechsler-Santos 2010) and $\mathrm{PE}(\mathrm{af})$. This is its first report from the State of Pernambuco and the Caatinga.

Material examined - Bahia, Santa Teresinha, Serra da Jibóia, 16 Mar 2002, A. Góes-Neto \& E.S. Santana 867 (HUEFS 106128, sub Phylloporia verae-crucis). Bahia, Senhor do Bonfim, Serra Maravilha, 13 Sep 2006, J.R.T. Vasconcellos-Neto 257 (HUEFS 133936, O). Pernambuco, Parque Nacional do Catimbau, Cachoeira do pingo, on living roots of liana, 4 Jul 2006, Drechsler-Santos DS040 (URM 80632, O). Pernambuco, Caruaru, Parque Ecológico Professor João de Vasconcelos Sobrinho, on soil, 25 Aug 2008, J.M. Baltazar et al., JMB 743 (URM 81306). Ibid, 3 Jun 2009, J.M. Baltazar et al. JMB 1697 (URM 81307). Pernambuco, Moreno, RPPN Carnijó, on soil, 17 Jun 2008, J.M. Baltazar \& L. Trierveiler-Pereira, JMB 392, 393 (URM 81308, 81309). Ibid, 8 Jul 2008, J.M. Baltazar et al., JMB 564 (URM 81310). Ibid, 14 Aug 2008, J.M. Baltazar et al., JMB 720 (URM 81311). Ibid, 23 Sep 2008, J.M. Baltazar \& L. Trierveiler-Pereira, JMB 969 (URM 81312). Ibid, 16 Oct 2008, J.M. Baltazar \& L. Trierveiler-Pereira, JMB 1135 (URM 81313). Ibid, 21 May 2009, J.M. Baltazar et al., JMB 1634 (URM 81314). Pernambuco, São Vicente Férrer, Mata do Estado (Sirijí), on soil, 18 Sep 2008, J.M. Baltazar \& L. Trierveiler-Pereira, JMB 1084 (URM 81315).

Notes - Because of the stipitate basidiomata, this species was widely accepted in Coltricia Gray. However, its small, coloured spores, and mainly the duplex pileal context and the presence of a black line below the pileal tomentum characterize it as typical Phylloporia Murrill species (Baltazar et al. 2010a). Its generic position is also supported by molecular data (Wagner \& Ryvarden 2002).

Phylloporia veracrucis (Sacc.) Ryvarden, another species which may have stipitate basidiomata, differs mainly by its slightly 
larger basidiospores (4-4.5 x 3-3.5 $\mu \mathrm{m}$ in this species, 3-4 x 2-3 $\mu \mathrm{m}$ in $P$. spathulata) (Wagner \& Ryvarden 2002).

A key for all accepted Phylloporia Murrill species is given in Wagner \& Ryvarden (2002), and Ryvarden (2004) provides a key to species known from the Neotropics.

Phanerochaetaceae Jülich

Antrodiella hydrophila (Berk. \& M.A. Curtis) Ryvarden, Mycotaxon 20(2): 343, 1984.

$\equiv$ Polyporus hydrophilus Berk. \& M.A. Curtis, J. Linn. Soc., Bot. 10(45): 306, 1868 [1869].

Description - Ginns (1980, sub Flaviporus Murrill) and Ryvarden \& Johansen (1980).

Known distribution - Pantropical (Ryvarden \& Johansen 1980); in Brazil: AL(af), PR(af), SP(af) (Baltazar \& Gibertoni 2009) and PE(af). This is its first report from the State of Pernambuco.

Material examined - Pernambuco, São Vicente Férrer, Mata do Estado (Sirijí), on a fallen trunk of unknown hardwood, 28 May 2009, J.M. Baltazar et al., JMB 1655, 1687 (URM 81466, 81467).

Notes - The flabelliform to spathulate and flexible basidiomata when fresh, tough and contracted when dry are the main characteristics of this species.

Microscopically A. hydrophila is similar to $A$. liebmannii (Fr.) Ryvarden, differing by the smaller basidiospores in the later $(2.5-3.5 \times 1.5-2.5 \mu \mathrm{m},(3-) 3.5 \times 2-2.5$ $\mu \mathrm{m}$ in $A$. hydrophila). Macroscopically they differ by the glabrous pileal surface in $A$. liebmannii, which is finely tomentose in $A$. hydrophila.

As for other species of this genus, the generic position of $A$. hydrophila is uncertain, and some authors have accepted it in Flaviporus or Tyromyces P. Karst. (Lowe 1975, Ginns 1980). Recent phylogenetic studies have shown that Antrodiella Ryvarden \& I. Johans. is polyphyletic (Miettinen 2011, Miettinen \& Larsson 2011), but A. hydrophilla was not included in those analyses.

A key to Antrodiella Ryvarden \& I. Johans. species known from the Neotropics is given in Ryvarden \& Iturriaga (2010).
Polyporaceae Fr. ex Corda

Datronia decipiens (Bres.) Ryvarden, Mycotaxon 33: 308, 1988.

$\equiv$ Trametes decipiens Bres., Ann.

Mycol. 18(1/3): 40, 1920.

Description - Ryvarden (1988).

Known distribution - Known only from Brazil: BA(ni), SP(af) and PE(af). This is its first report from the State of Pernambuco.

Material examined - Pernambuco, Caruaru, Parque Ecológico Professor João de Vasconcelos Sobrinho, on a fallen dead branch of unknown hardwood, 26 Nov 2008, J.M. Baltazar et al., JMB 1283 (URM 81656).

Notes - Datronia decipiens is characterized by the thin, effuse-reflexed basidioma, duplex context with a black line separating the upper and lower parts, large pores and ellipsoid, slightly thick-walled basidiospores. The pores and basidiospores features separate it from other Datronia Donk species (Ryvarden 1988).

There are few collections of this species until now. The type was collected in the State of Bahia, and there is one specimen from São Paulo (Brazil) and another from Colombia, both in $\mathrm{O}$.

Flabellophora parva Corner, Beih. Nova Hedwigia 86: 42, 1987.

Description - Corner (1987).

Known distribution - Known only from the type locality in Peru and Brazil (Corner 1987, Ryvarden \& Meijer 2002); in Brazil: PR(ex) (Ryvarden \& Meijer 2002) and PE(af). This is its first report from the Atlantic Forest and the Northeast Region.

Material examined - Pernambuco, Caruaru, Parque Ecológico Professor João de Vasconcelos Sobrinho, on a fallen trunk of unknown hardwood, 30 Sep 2008, J.M. Baltazar \& L. Trierveiler-Pereira, JMB 1017 (URM 81738). Ibid, 29 Oct 2008, J.M. Baltazar et al., JMB 1199 (URM 81739). Ibid, 26 Nov 2008, J.M. Baltazar et al. JMB, 1287 (URM 81740). Ibid, 17 Mar 2009, J.M. Baltazar et al., JMB 1494 (URM 81741).

Notes - Flabellophora parva is characterized by two or more pilei superposed in the same stipe, but young specimens may present a single pileus. Flabellophora 


\section{Key to Datronia species known from the Brazilian Atlantic Forest}

1. Hyphal system trimitic Coriolopsis Murrill ${ }^{1}$

1. Hyphal system dimitic with arboriform skeleto-binding hyphae 2

2. Pores angular to daedaloid and large, 1-2 per mm 3

2. Pores round to hexagonal and smaller, 4-5 per $\mathrm{mm}$ 4

3. Basidiospores ellipsoid, slightly thick-walled, 12-14(-16) x 5-8 $\mu \mathrm{m}$ D. decipiens

3. Basidiospores cylindrical to oblong-ellipsoid, thin-walled, 6-11 x 3-4 $\mu \mathrm{m}$

D. mollis (Sommerf.: Fr.) Donk

4. Pileus ungulate to triquetrous, pileal surface glabrous, often sulcate, dark brown to black, basidiospores $8-10 \times 3-4 \mu \mathrm{m}$ D. scutellata (Schwein.) Gilb. \& Ryvarden

4. Pileus resupinate to effuse-reflexed, pileal surface tomentose to strigose, even, pale brown to brown, basidiospores $8-12 \times 3.5-4.5 \mu \mathrm{m}$ D. stereoides (Fr.: Fr.) Ryvarden

superposita (Berk.) G. Cunn. also has superposed pilei, but the generative hyphae in the pileus are simple-septated.

Flabellophora obovata (Jungh.) Núñez \& Ryvarden shares with $F$. parva a monomitic context. However, the later has a beige to pale cream, azonate to radially striate pileal surface, while the former has a vinaceous to brownish beige, concentrically zonate pileal surface. The basidiospores of $F$. obovata are wider (3-4 $\mu \mathrm{m}$ versus $2(-2.5) \mu \mathrm{m}$ in $F$. parva).

The septation of the type species of Flabellophora G. Cunn. is controversial, and perhaps the genus could be restrict to $F$. superposita. For discussions of this issue cf. Cunningham (1965), Corner (1987) and Hattori (2000).

Pachykytospora alabamae (Berk. \& Cooke) Ryvarden, Norweg. J. Bot. 19: 233, 1972.

$\equiv$ Polyporus alabamae Berk. \& Cooke, Grevillea 6(40): 130, 1878. (1987).

Description - Gilbertson \& Ryvarden

Known distribution - Tropical and subtropical (Gilbertson \& Ryvarden 1987); in Brazil: PA(am), PR(af), RR(am), RS(af), SC(af), SP(af) (Baltazar \& Gibertoni 2009, Gomes-Silva \& Gibertoni 2009) and PE(af). This is its first report from the Northeast Region.

Material examined - Pernambuco, São Vicente Férrer, Mata do Estado (Sirijî), on fallen dead trunk of unkown hardwood, 28 Aug 2008, J.M. Baltazar \& L. Trierveiler-Pereira, JMB 789 (URM 81795). Ibid, 18 Sep 2008, J.M. Baltazar \& L. Trierveiler-Pereira, JMB 894 (URM 81796).

Notes - There are three species of Pachykytospora Kotl. \& Pouzar known from the Neotropics until now: $P$. alabamae, $P$. papyraceae and $P$. nanospora A. David \& Rajchenb. The two former are similar, and differ by the pore and basidiospore size (4-5 pores per mm, basidiospores $8-12 \times 4-6 \mu \mathrm{m}$ in $P$. alabamae and 2-4 pores per $\mathrm{mm}$, basidiospores $12.5-15 \times$ x $6-7 \mu \mathrm{m}$ in $P$. papyracea). Pachykytospora nanospora has ellipsoid, smaller basidiospores (5-6 (-6.5) x 3-4 $\mu \mathrm{m}$ ) (David \& Rajchenberg 1992).

Pachykytospora papyracea (Schwein.) Ryvarden, Norweg. J. Bot. 19: 233, 1972. $\equiv$ Boletus papyraceus Schwein., Schr. naturf. Ges. Leipzig 1: 991822.

Description - Gilbertson \& Ryvarden (1987).

Known distribution - Cosmopolitan (Gilbertson \& Ryvarden 1987); in Brazil: RS(af), SC(af), SP(af, ce) (Baltazar \& Gibertoni 2009, Gibertoni \& Drechsler-Santos 2010, Gugliotta et al. 2010) and PE(af). This is its first report from the Northeast Region.

Material examined - Pernambuco, Caruaru, Parque Ecológico Professor João de Vasconcelos Sobrinho, on a fallen drunk of

\footnotetext{
${ }^{1}$ Many authors accept trimitic species in Datronia and include other taxa in this genus, such as Polyporus caperatus Berk. We accept only dimitic species in Datronia and consider P. caperatus in Coriolopsis.
} 


\section{Key to Flabellophora species known from Brazil}

1. Pileus large, usually above $10 \mathrm{~cm}$ in diam., basidiospores up to $3 \mu \mathrm{m}$ in the largest dimension ..... F. ochracea Corner.

1. Pileus smaller, usually up to $6 \mathrm{~cm}$ in diam., basidiospores more than $3.5 \mu \mathrm{m}$ in the largest dimension

2. Pilei single to usually superposed in a single stipe, pileal surface azonated to radially striated, whitish to pale cream, basidiospores 3.5-4 (-4.5) x (2-) $2.5 \mu \mathrm{m}$ F. parva

2. Pilei single to imbricate, pileus surface concentrically zonated, vinaceous to beige and brown when fresh, becoming cream and greyish when dry, basidiospores $4-5 \times 3-4 \mu \mathrm{m} \ldots \ldots . . F$. obovata

unknown hardwood, 25 Aug 2008, J.M. Baltazar et al., JMB 746 (URM 81797).

Notes - Pachykytospora papyracea is similar to $P$. alabamae, from which it differs by the larger pores and basidiospores (see discussion under P. alabamae).

Dichomitus cavernulosus Masuka \& Ryvarden has similar basidiomata with the same pore size and also dextrinoid skeletal hyphae. It differs by having skeleto-binding hyphae and smooth basidiospores.

Polyporus arcularius (Batsch) Fr., Syst. mycol. 1: 342, 1821.

$\equiv$ Boletus arcularius Batsch, Elench. fung.: 97, 1783.

Description - Núñez \& Ryvarden (1995) and Silveira \& Wright (2005).

Known distribution - Cosmopolitan (Núñez \& Ryvarden 1995); in Brazil: PA(am), PR(af), $\quad$ RO(af), $\quad$ RS(af), $\quad$ SC(af), $\quad$ SP(af) (Baltazar \& Gibertoni 2009, Gomes-Silva \& Gibertoni 2009) and PE(af). This is its first report from the Northeast Region.

Material examined - Pernambuco, Recife, Parque Dois Irmãos, on dead fallen trunk of unknwon hardwood, 7 May 2009, J.M. Baltazar \& L. Trierveiler-Pereira, JMB 1536 (URM 81805).

Notes - This species is characterized by its hexagonal and elongated pores. Following Silveira \& Wright (2005), P. arcularius differs from $P$. arcularioides A. David \& Rajchen. by the presence of scales in the pileal surface, ciliate margin and hyphal pegs in the former. However, the presence of scales and cilia seems to be variable (Núñez \& Ryvarden 1995).

We have not found hyphal pegs in the examined material, but the taxonomic importance of this structure has been discussed in many polypore genera (Fidalgo 1968a, Gomes-Silva et al. 2010a). Otherwise, this specimen agrees with the morphological species concept.

Keys to species of Polyporus P. Micheli ex Adans. are given by Núñez \& Ryvarden (1995) and Silveira \& Wright (2005).

Polyporus puttemansii Henn., Hedwigia 43: 200, 1904.

Description - David \& Rajchenberg (1985) and Silveira \& Wright (2005).

Known distribution - Netropical and subtropical, known from Argentina, Brazil and Guiana (David \& Rajchenberg 1985, Silveira \& Wright 2005); in Brazil: PR(af), RS(af), SP(af) (Baltazar \& Gibertoni 2009) and PE(af). This is its first record from the Northeast Region.

Material examined - Pernambuco, São Vicente Férrer, Mata do Estado (Sirijî), on fallen dead trunk of unknown hardwood, 19 Sep 2008, J.M. Baltazar et al., JMB 621 (URM 81886). Ibid, 19 Mar 2009, J.M. Baltazar \& L. Trierveiler-Pereira, JMB 1513, 1514, 1516, 1520 (URM 81887, 81888, 81889, 81890).

Notes - This species is characterized by its slightly central stipe and its large pores.

Silveira \& Wright (2005) treat this species as a variety of $P$. guianensis Mont. The studied material, however, is different from specimens collected in Pernambuco and determined as $P$. guianensis and we prefer to treat them as separate species. Specimens of $P$. Puttemansii have a thin, cartilaginous and fragile pileus, while in $P$. guianensis they are thicker, coriaceous and tough. The stipe insertion is also different is these species, and our specimens of $P$. guianensis always have a 


\section{Key to Pachykytospora Kotl. \& Pouzar species known from the Neotropics}

1. Basidiospores ellipsoid, 5-6(-6.5) $\mu \mathrm{m}$ in the largest dimension .............................. nanospora

1. Basidiospores cylindrical to oblong-ellipsoid, more than $8 \mu \mathrm{m}$ in the largest dimension 2

2. Pores 4-5 per mm, basidiospores 8-12 x 4-6 $\mu \mathrm{m}$ P. alabamae

2. Pores $2-4$ per $\mathrm{mm}$, basidiospores $12.5-15 \times 6-7 \mu \mathrm{m}$ P. papyracea

laterally attached stipe. In our conception, $P$. guianensis is closer to P. leprieurii Mont., with which it shares the production of rhizomorphlike structures.

Tinctoporellus epimiltinus (Berk. \& Broome) Ryvarden, Trans. Br. Mycol. Soc. 73(1): 18, 1979.

$\equiv$ Polyporus epimiltinus Berk. \& Broome, J. Linn. Soc., Bot. 14(2): 54, 1875. (1980).

Description - Ryvarden \& Johansen

Known distribution - Pantropical (Ryvarden \& Johansen 1980). In Brazil: PR(af), SC(af), SP(af) (Baltazar \& Gibertoni 2009, Gugliotta et al 2010) and PE(af, ca). This is its first record from the Northeast Region and the Caatinga.

Material examined - Bahia, Santa Teresinha, Serra da Jibóia, on wood, 11 Jan 2006, P. Oinonen, et al. (HUEFS 108313, sub Trametes sp., O). Pernambuco, Moreno, RPPN Carnijó, on fallen dead trunk of an unknown angiosperm, 17 Jun 2008, J.M. Baltazar \& L. Trierveiler-Pereira, JMB 419 (URM 81915). Ibid, 8 Jul 2008, J.M. Baltazar et al., JMB 544 (URM 81916). Ibid, 16 Oct 2008, J.M. Baltazar \& L. Trierveiler-Pereira, JMB 1101, 1129 (URM 81918, 81919). Ibid, 21 Nov 2008, J.M. Baltazar \& L. Trierveiler-Pereira, JMB 1260 (URM 81920).

Notes - This species is easily identifiable in the field because of its greyish to bluish colour, tiny pores, and the reddish colour of the substrate (Ryvarden \& Johansen 1980). Tinctoporellus isabelinus Ryvarden \& Iturr. differs by the presence of cystidia and by the shape and size of basidiospores (cyllindric, 3-3.5 x $1 \mu \mathrm{m}$ in T. isabelinus and ellipsoid, 4$4.5 \times 2-3 \mu \mathrm{m}$ in $T$. epimiltinus (Ryvarden \& Iturriaga 2003). Following these authors, the change of color of the substrata is also more subtle in the former.
A key to Tinctoporellus Ryvarden species known from the Neotropics is given in Ryvarden \& Iturriaga (2003).

Trametes lactinea (Berk.) Sacc., Syll. fung. 6: 343, 1888.

$\equiv$ Polyporus lactineus Berk., Ann. Mag. nat. Hist., Ser. 1, 10: 373, 1842.

Description - Ryvarden \& Johansen (1980) and Corner (1989b).

Known distribution - Pantropical (Ryvarden \& Johansen 1980); in Brazil: AC(am), AM(am), PA(am), RO(am) (GomesSilva et al. 2010b) PE(af) and SE(ca). This is its first report from the Northeast Region, the Atlantic Forest and the Caatinga.

Material examined - Pernambuco, Recife, Parque Dois Irmãos, on a fallen dead trunk of unknown hardwood, 12 Aug 2008, J.M. Baltazar et al., JMB 664 (URM 81924). Pernambuco, Parque Nacional do Catimbau, Trilha das Torres, on dead tree of Canzenzo, 8 Dec 2006, Drechsler-Santos DS102 (URM 80892, O). Sergipe, Portão da Folha, on dead wood, 15 Jun 2008, Drechsler-Santos DS032SE (URM 80427, O).

Notes - This species is similar to $T$. elegans (Spreng.) Fr., from which differs by the sinuous to daedaloid hymenophore and by the hyphal endings, which project beyond the hymenium in the later (Corner 1989b).

Trametes incana Lév. is also similar, but has a zoned and brownish pileal surface (Ryvarden \& Johansen 1980).

Keys to species of Trametes Fr. are given in Ryvarden \& Johansen (1980), Corner (1989b) and Gomes-Silva et al. (2010b).

Truncospora ochroleuca (Berk.) Pilát, Sb. Nár. Mus. v Praze, Rada B, Prír. Vedy 9(2):

108, 1953. $\equiv$ Polyporus ochroleucus Berk., Hooker's J. Bot. Kew Gard. Misc. 4: 53, 1845. 
Description - Ryvarden \& Johansen (1980) and Corner (1989a).

Known distribution - Cosmopolitan (Ryvarden \& Johansen 1980); in Brazil: RS(af), SC(af) (Baltazar \& Gibertoni 2009) and $\mathrm{PE}(\mathrm{af})$. This is its first report from the Northeast Region.

Material examined - Pernambuco, Caruaru, Parque Ecológico Professor João de Vasconcelos Sobrinho, on a fallen drunk of unknown hardwood, 20 Jun 2008, J.M. Baltazar et al., JMB 444, 451 (URM 81803, 81804). Pernambuco, Parque Nacional do Catimbau, Trilha das Torres, 8 Dec 2006, Drechsler-Santos (URM 80806, URM 80862).

Notes - Truncospora ochroleuca is very similar to $T$. ohiensis (Berk.) Pilát, superposing basidiospore size range. However, the later has a black to grey pileal surface and smaller pores (2-4 in T. ohiensis and 5-7 per $\mathrm{mm}$ in T. ochroleuca) (Loguercio-Leite et al. 2008, Trierveiler-Pereira et al. 2009). Corner (1989a) considers these differences irrelevant and treats them as synonyms.

Truncospora detrita (Berk.) Decock is also very similar to those species, but has smaller basidiospores (10.1-)10.3-12.5(-13) x (5.5-)6.2-7.8 $\mu \mathrm{m}$. Decock \& Ryvarden (1999) asserted that these three species are very homogenous and compatibility tests are needed to confirm how many species are in this complex. At this time being, we prefer to treat them as separated species.

Truncospora ochroleuca was largely accepted in Perenniporia Murrill. Recently, Decock (2011) reintroduced the genus Truncospora Pilát with a redefined circumscription. This taxonomic position is supported by morphological and molecular data (Robledo et al. 2009).

A key to pileate species of Perenniporia s.l. known from the Neotropics is given in Decock \& Ryvarden (2003).

Schizoporaceae Jülich

Schizopora flavipora (Berk. \& M.A. Curtis ex Cooke) Ryvarden, Mycotaxon 23: 186, 1985.

$\equiv$ Poria flavipora Berk. \& M.A. Curtis ex Cooke, Grevillea 15(73): 25, 1886.

Description - Gilbertson \& Ryvarden (1986) and $\mathrm{Wu}(2000)$.
Known distribution - Pantropical and pantemperate (Wu 2000); in Brazil: AL(af), PA(am), PB(af), PR(af), RN(af), SC(af), SP(af) (Baltazar \& Gibertoni 2009, Gomes-Silva \& Gibertoni 2009) and PE(af, ca). This is its first record from the State of Pernambuco and the Caatinga.

Material examined - Pernambuco, Caruaru, Parque Ecológico Professor João de Vasconcelos Sobrinho, on hardwood wood, 25 Aug 2008, J.M. Baltazar et al., JMB 766, 769, 773 (URM 81316, 81317, 81318). Ibid, 30 Sep 2008, J.M. Baltazar \& L. Trierveiler-Pereira, JMB 1014, 1021 (URM 81319, 81320). Ibid, 29 Oct 2008, J.M. Baltazar et al., JMB 1201 (URM 81321). Ibid, 26 Nov 2008, J.M. Baltazar et al., JMB 1290 (URM 81322). Ibid, 27 Jan 2009, J.M. Baltazar \& L. TrierveilerPereira, JMB 1370 (URM 81323). Ibid, 17 Mar 2009, J.M. Baltazar et al., JMB 1490, 1492 (URM 81324, 81325). Ibid, 03 Jun 2009, J.M. Baltazar et al., JMB 1705 (URM 81326). Pernambuco, Moreno, RPPN Carnijó, on hardwood Wood, 14 Aug 2008, J.M. Baltazar et al., JMB 704 (URM 81327). Ibid, 23 Sep 2008, J.M. Baltazar \& L. Trierveiler-Pereira, JMB 957, 961 (URM 81328, 81329). Ibid, 16 Oct 2008, J.M. Baltazar \& L. TrierveilerPereira, JMB 1108, 1123 (URM 81330, 81331). Ibid, 12 Mar 2009, J.M. Baltazar \& L. Trierveiler-Pereira, JMB 1454 (URM 81332). Recife, Parque Dois Irmãos, on hardwood wood, 07 Jul 2008, J.M. Baltazar et al., JMB 521 (URM 81333). Ibid, 16 Sep 2008, J.M. Baltazar et al., JMB 834, 854, 859 (URM 81334, 81335, 81336). Ibid, 15 Oct 2008, J.M. Baltazar \& L. Trierveiler- Pereira, JMB 1073 (URM 81337). Ibid, 19 Nov 2008, J.M. Baltazar \& L. Trierveiler-Pereira, JMB 1228 (URM 81338). Pernambuco, São Vicente Férrer, Mata do Estado (Sirijî), on hardwood wood, 19 Jul 2008, J.M. Baltazar et al., JMB 615 (URM 81339). Ibid, 28 Aug 2008, J.M. Baltazar \& L. Trierveiler-Pereira, JMB 783 (URM 81340). Ibid, 18 Sep 2008, J.M. Baltazar \& L. Trierveiler-Pereira, JMB 885, 917 (URM 81341, 813342). Ibid, 21 Oct 2008, J.M. Baltazar et al., JMB 1180 (URM 81343). Ibid, 30 Nov 2008, J.M. Baltazar et al., JMB 1294 (URM 81344). Pernambuco, Parque Nacional do Catimbau, Morro do Cachorro, on 
dead brunches in the soil, 16 Apr 2007, Drechsler-Santos DS218 (URM 80547, O).

Notes - This species is close to $S$. paradoxa (Schrad.) Donk, from which differs by the hymenophore and the basidiospore size (hymenophore distinctly poroid, basidiospores 3.5-5 x 2.5-3.5 $\mu \mathrm{m}$ in S. flavipora, and hymenophore irregularly poroid to irpicoid, basidiospores $5-6(-6.5) \times 3.5-4 \mu \mathrm{m}$ in $S$. paradoxa).

Gugliotta et al. (2010) reports $S$. trichilie (Van der Byl) Ryvarden from the State of São Paulo. Following Langer (1994) and Hjortstam \& Ryvarden (2009), this species is a synonym of $S$. flavipora.

Keys to species of Schizopora and Hyphodontia s.l. are given in Langer (1994) and Langer et al. (1995).

\section{Acknowledgements}

The authors are in debt with the directors and staff in charge of the surveyed areas for allowing our access for collecting. We also thank, Georgea S. Nogueira Melo for help with the revision of some specimens, and Felipe Wartchow, Gilson Régio (Mata do Estado), José Luciomario de Araújo (Brejo dos Cavalos), Larissa Trierveiler Pereira, Victor Rafael M. Coimbra, Mônica Antunes Ulyssèa, and Valéria Santana for support during the field trips. This research was partially financed by the 'Fundação de Amparo à Ciência e Tecnologia do Estado de Pernambuco (FACEPE, APQ-0444-2.03/08)', The 'Conselho Nacional de Desenvolvimento Científico e Tecnológico' (CNPq) provided a master scholarship for JMB (GM 131724/2008-8) and $\mathrm{PhD}$ scholarships for ERDS (GD 141072/2006-7 and SWE 201847/2008-6). CNPq also financed partially this research (Projects: Universal 478973/2006-3 and 479961/2007-7, and Pesquisa em Biodiversidade do Semi-árido 010105.00/2004/PPBio).

\section{References}

Baltazar JM, Gibertoni TB. 2009 - A checklist of the aphyllophoroid fungi (Basidiomycota) recorded from the Brazilian Atlantic Forest. Mycotaxon 109, 439442.
Baltazar JM, Gibertoni TB. 2010 - New combinations in Phellinus s.l. and Inonotus s.l. Mycotaxon 111, 205-208.

Baltazar JM, Trierveiler-Pereira L, LoguercioLeite C. 2009a - A checklist of xylophilous basidiomycetes (Basidiomycota) in mangroves. Mycotaxon 107, 221-224.

Baltazar JM, Trierveiler-Pereira L, LoguercioLeite C, Ryvarden L. 2009b - Santa Catarina Island mangroves 3: a new species of Fuscoporia. Mycologia 101, 859-863.

Baltazar JM, Ryvarden L, Gibertoni TB. 2010a - The genus Coltricia in Brazil: new records and two new species. Mycologia 102, 1253-1262.

Baltazar JM, Trierveiler-Pereira L, Ryvarden L, Loguercio-Leite C. 2010b - Inonotus s.1. (Hymenochaetales) in the Brazilian herbaria FLOR and SP. Sydowia 62, 1-9.

Burdsall HH Jr., Banik MT. 2001. The genus Laetiporus in North America. Harvard Papers in Botany 6, 43-55.

Campacci TVS, Gugliotta A de M. 2009 - A review of Amauroderma in Brazil, with A. oblongisporum newly recorded from the neotropics. Mycotaxon 110, 423-436.

Coelho G, Silveira RMB da, Guerrero RT, Rajchenberg M. 2009 - On poroid Hymenochaetales growing on bamboos in Southern Brazil and NE Argentina. Fungal Diversity 36, 1-8.

Corner EJH. 1987 - Ad Polyporaceas IV. Beihefte zur Nova Hedwigia 86, 1-265.

Corner EJH. 1989a - Ad Polyporaceas V. Beihefte zur Nova Hedwigia 96, 1-218.

Corner EJH. 1989b - Ad Polyporaceas VI. Beihefte zur Nova Hedwigia, 1-197.

Cunningham GH. 1965 - Polyporaceae of New Zealand. New Zealand Department of Scientific and Industrial Research Bulletin 164, 1-304.

David A, Rajchenberg M. 1985 - Pore fungi from French Antilles and Guiana. Mycotaxon 22, 285-325.

David A, Rajchenberg M. 1992 - West African polypores: new species and combinations. Mycotaxon 45, 131-148.

Decock C. 2011 - Studies in Perenniporia s.1. (Polyporaceae): African taxa VII. Truncospora oboensis sp. nov., an undes- 
cribed species from high elevation cloud forest of São Tome. Cryptogamie Mycologie 32, 383-390.

Decock C, Ryvarden L. 1999 - Studies in Perenniporia: Perenniporia detrita and its taxonomic synonyms. Mycologia 91, 386-395.

Decock C, Ryvarden L. 2003 - Perenniporiella gen. nov. segregated from Perenniporia, including a key to neotropical Perenniporia species with pileate basidiomes. Mycological Research 107, 93-103.

Drechsler-Santos ER, Ryvarden L, Wartchow F, Cavalcanti MAQ. 2008 - Polyporus elongoporus (Aphyllophorales, Poriaceae) sp. nov. Synopsis Fungorum 25, 3843.

Drechsler-Santos ER, Gibertoni TB, Cavalcanti MAQ. 2009 - A re-evaluation of the lignocellulolytic Agaricomycetes from the Brazilian semi-arid region. Mycotaxon 108, 241-244 (in http://Mycotaxon.com/resources/weblists.html).

Drechsler-Santos ER, Santos PJP, Gibertoni TB, Cavalcanti MAQ. 2010 - Ecological aspects of Hymenochaetaceae in an area of Caatinga (semi-arid) in Northeast Brazil. Fungal Diversity 42, 71-78.

Fidalgo O. 1968a - As microestruturas e sua importância na sistemática dos fungos superiores. Rickia 3, 117-159.

Fidalgo O. 1968b - Phellinus pachyphloeus and its allies. Memoirs of the New York Botanical Garden 17, 109-147.

Gibertoni TB, Drechsler-Santos ER. 2010 Lignocellulolytic Agaricomycetes from the Brazilian Cerrado biome. Mycotaxon 111, 87-90.

Gibertoni TB, Drechsler-Santos ER, Baltazar JM, Gomes-Silva AC, Nogueira-Melo GS, Ryvarden L, Cavalcanti MAQ. 2011 - The genus Trichaptum (Agaricomycetes, Basidiomycota) in Brazil. Nova Hedwigia 93, 85-96.

Gilbertson RL, Ryvarden L. 1986 - North American Polypores. Vol. 1. Abortiporus-Lindtneria. Oslo, Fungiflora.

Gilbertson RL, Ryvarden L. 1987 - North American Polypores. Vol. 2. Megasporoporia-Wrightoporia. Oslo, Fungiflora.

Ginns J. 1980 - The genus Flaviporus Murrill
(Polyporaceae). Canadian Journal of Botany 58, 1578-1590.

Góes-Neto A. 1999 - Polypore diversity in the state of Bahia, Brazil: a historical review. Mycotaxon 72, 43-76.

Gomes-Silva AC, Gibertoni TB. 2009 Checklist of the aphyllophoraceous fungi (Agaricomycetes) of the Brazilian Amazonia. Mycotaxon 108, 319-322.

Gomes-Silva AC, Baltazar JM, Ryvarden L, Gibertoni TB. 2010a - Amauroderma calcigenum (Ganodermataceae, Basidiomycota) and its presumed synonym $A$. partitum. Nova Hedwigia 90, 449-455.

Gomes-Silva AC, Ryvarden L, Gibertoni TB. 2010b - Notes on Trametes from the Brazilian Amazonia. Mycotaxon 113, 61-71.

Gugliotta A de M, Fonsêca MP da, Bononi VLR. 2010 - Additions to the knowledge of aphyllophoroid fungi (Basidiomycota) of Atlantic Rain Forest in São Paulo State, Brazil. Mycotaxon 112, 335-338.

Hattori T. 2000 - Type studies of the polypores described by E. J. H. Corner from Asia and the West Pacific I. Species described in Polyporus, Buglossoporus, Meripilus, Daedalea, and Flabellophora. Mycoscience 41, 339-349.

Hjortstam K, Ryvarden L. 2009 - A checklist of names in Hyphodontia sensu strictu sensu lato and Schizopora with new combinations in Lagarobasidium, Lyomyces, Kneiffiella, Schizopora and Xylodon. Synopsis Fungorum 26, 33-55.

IBGE. 2011. Mapa de Biomas e Vegetação. <http://www.ibge.gov.br/home/presidenc ia/noticias/ 21052004biomas.shtm>. [Accessed June 2011].

Langer E. 1994. Die Gattung Hyphodontia John Eriksson. Bibliotheca Mycologica 154, 1-298.

Langer E, Langer G, Oberwinkler F. 1995. Digital exsiccate of fungi 1995. <http://www.unituebingen.de/uni/bbm/m ycology/homepage.htm>. [Accessed June 2011].

Lindner DL, Banik MT. 2008. Molecular phylogeny of Laetiporus and other brown rot polypore genera in North America. Mycologia 100, 417-430.

Loguercio-Leite C, Michels J, Baltazar JM. 
2008 - Austro-American lignolytic polypores (Agaricomycetes) — new records for Southern Brazil. Mycotaxon 104, 205-213.

Lowe JL. 1957 - Polyporaceae of North America. The genus Fomes. Technical Publications. New York State University College of Forestry 80, 1-97.

Lowe JL. 1975 - Polyporaceae of North America. The genus Tyromyces. Mycotaxon 2, 1-82.

Meijer AAR de. 2010 - Preliminary list of the macromycetes from the Brazilian state of Paraná: corrections and updating. Boletim do Museu Botânico Municipal, Curitiba (72): 1-9.

Miettinen O. 2011. Taxonomy and phylogeny of white-rot polypores: case studies in Hymenochaetales and Polyporales (Basidiomycota). Publication in Botany from University of Helsinki No 41, 9 p.

Miettinen O, Larsson KH. 2011. Sidera, a new genus in Hymenochaetales with poroid and hydnoid species. Mycological Progress 10, 131-141.

Núñez M, Ryvarden L. 1995 - Polyporus (Basidiomycotina) and related genera. Synopsis Fungorum 10: 1-85.

Reck MA, Silveira RMB da. 2009 Grammothele species from southern Brazil. Mycotaxon 109, 361-372.

Reck MA, Westphalen MC, Silveira RMB da. 2011 - Rediscovery of Microporellus iguazuensis in southern Brazil. Mycotaxon 115, 5-10.

Robledo GL, Amalfi M, Castillo G, Rajchenberg M, Decock C. 2009 Perenniporiella chaquenia sp. nov. and further notes on Perenniporiella and its relationships with Perenniporia (Poriales, Basidiomycota). Mycologia 101, 657-673.

Ryvarden L. 1988 - Type studies in the Polyporaceae - 20. Species described by G. Bresadola. Mycotaxon 33, 303-327.

Ryvarden L. 2004 - Neotropical polypores Part 1 - Introduction, Ganodermataceae \& Hymenochaetaceae. Synopsis Fungorum 19, 1-229.

Ryvarden L. 2005 - The genus Inonotus a synopsis. Synopsis Fungorum 19, 1-149. Ryvarden L, Iturriaga T. 2003 - Studies in neotropical polypores 10 . New polypores from Venezuela. Mycologia 95, 10661077.

Ryvarden L. Iturriaga T. 2010 - Studies in Neotropical polypores 29 Some new and interesting species from the Andes region in Venezuela. Synopsis Fungorum 27, 78-91.

Ryvarden L, Johansen I. 1980 - A preliminary polypore flora of East Africa. Oslo, Fungiflora.

Ryvarden L, Meijer AAR de. 2002 - Studies in neotropical polypores $14-\mathrm{New}$ species from the state of Paraná, Brazil. Synopsis Fungorum 15, 34-69.

Silveira RMB da, Wright JE. 2005 - The taxonomy of Echinochaete and Polyporus s. str. in southern South America. Mycotaxon 93, 1-59.

Silveira RMB da, Reck MA, Graf LV, Sá FN de. 2008 ["2009"] - Polypores from a Brazilian pine forest in Southern Brazil: pileate species. Hoehnea 35, 619-630.

Thiers B. [continuously updated] - Index Herbariorum: A global directory of public herbaria and associated staff. New York Botanical Garden's Virtual Herbarium.

Trierveiler-Pereira L, Baltazar JM, LoguercioLeite C. 2009 - Santa Catarina Island mangroves 4 - xylophilous basidiomycetes. Mycotaxon 109, 107-110.

Wagner T, Ryvarden L. 2002 - Phylogeny and taxonomy of the genus Phylloporia (Hymenochaetales). Mycological Progress 1, 105-116.

Westphalen MC, Reck MA, Silveira RMB da. 2010a - Ganoderma chalceum and Junghuhnia meridionalis: new records from Brazil. Mycotaxon 111, 11-18.

Westphalen MC, Reck MA, Silveira RMB da. 2010b - Polypores from Morro Santana, Rio Grande do Sul, Brazil. Hoehnea 37, 647-662.

Wu SH. 2000 - Studies on Schizopora flavipora s.l., with special emphasis on specimens from Taiwan. Mycotaxon 76, 51-66. 